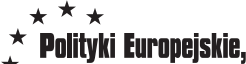

$\star$ Finanse i Marketing

$\star \star \star 15(64) 2016$

Lukasz Satola

Uniwersytet Rolniczy w Krakowie

\title{
Wykorzystanie funduszy Unii Europejskiej na inwestycje komunalne a ograniczanie zadłużenia samorządów
}

\section{THE USE OF EUROPEAN UNION FUNDS FOR MUNICIPAL INVESTMENTS AND LIMITING DEBT OF LOCAL GOVERNMENTS}

\begin{abstract}
Integracja europejska $w$ znaczqcym stopniu zmienita warunki funkcjonowania jednostek samorzadu terytorialnego glównie za sprawa dostępności funduszy strukturalnych. Obecnie wiele podejmowanych przez gminy działań, szczególnie inwestycyjnych odbywa się przy udziale dofinansowania w ramach instrumentów polityki regionalnej UE. Pozyskane fundusze z jednej strony stanowiq wsparcie dla lokalnych budżetów, z drugiej zaś powoduja wzrost wydatków, które często finansowane sq z kredytów.

Celem artykulu jest identyfikacja relacji zachodzacych pomiędzy zrealizowanymi przy wsparciu finansowym inwestycjami komunalnymi a nowo wprowadzonymi wskaźnikami zadtużenia. Polskie gminy cechowało duże zróżnicowanie poziomu wykorzystania funduszy UE. Nowe limity zadhużenia moga ograniczać zdolności absorpcyjne samorzqdów w konsekwencji splat odsetek od zaciaganych w przeszłości zobowiqzań.
\end{abstract}

Słowa kluczowe: ekonomia sektora publicznego, fundusze strukturalne, gmina, polityka regionalna, sytuacja finansowa gmin, zadłużenie

\section{Wstęp}

Jednostki samorządu terytorialnego (JST) zaliczane są do tej części sektora publicznego, której zadaniem jest dostarczanie dóbr i usług publicznych w zdecentralizowany sposób. Jak wskazują międzynarodowe doświadczenia zastosowanie lokalnego podejścia (decentralizacja funkcji państwa) prowadzi do osiagania wyższej wartości efektywności alokacyjnej wydatków publicznych ${ }^{1}$. Samorząd terytorialny w większym stopniu niż władze centralne odwzorowuje skalę preferencji lokalnych, co w konsekwencji powoduje lepsze rozpoznanie i adresowanie usług publicznych.

Podejmowane przez samorządy zadania służą zarówno bieżącemu funkcjonowaniu, jak i realizacji przedsięwzięć inwestycyjnych, bez których nie może dokonywać się rozwój jednostki terytorialnej². Realizacja niektórych zadań publicznych

\footnotetext{
${ }^{1}$ Oates W., Fiscal federalism, Harcourt Brace Jovanovich, New York 1972.

${ }^{2}$ Por. Prus P., Wawrzyniak B. M. Zarządzanie projektami i funkcje gmin w zakresie programów rozwoju obszarów wiejskich. Studia i Materiaty Polskiego Stowarzyszenia Zarzqdzania Wiedza, 2011, nr 44, s. 77-92.
} 
odbywa się na zasadzie współpracy (związku, porozumienia) z innymi jednostkami administracji publicznej ${ }^{3}$. Zadania te stanowią podstawowe narzędzie wykorzystywane w procesie planowania oraz wdrażania w życie zróżnicowanych koncepcji rozwoju. Mogą one bowiem stymulować lub hamować tempo oraz zakres przemian w zależności od stanu i poziomu zróżnicowania zasobów, a także stopnia atrakcyjności i konkurencyjności przestrzeni społeczno-gospodarczej, jakim charakteryzuje się dana jednostka samorządu terytorialnego ${ }^{4}$.

Od momentu integracji Polski ze strukturami UE duże zmiany nastąpiły szczególnie w zakresie podejmowania przez samorządy działalności inwestycyjnej. Pojawiły się bowiem możliwości uzyskania dofinansowania $\mathrm{w}$ ramach wdrażanych instrumentów polityki regionalnej.

Realizacja projektów inwestycyjnych, w tym również współfinansowanych z funduszy UE wymaga od JST dużego zaangażowania finansowego, które często przekracza ich możliwości budżetowe. W takich sytuacjach konieczne jest korzystanie ze zwrotnych źródeł finansowania, tzn. zaciąganie kredytów, a w przypadku części samorządów również emisja obligacji komunalnych. Wszystkie te sposoby prowadzą w konsekwencji do wzrostu zadłużenia.

Celem artykułu jest identyfikacja relacji zachodzących pomiędzy zrealizowanymi przy wsparciu finansowym inwestycjami komunalnymi a nowo wprowadzonymi wskaźnikami zadłużenia.

\section{Material i metodyka opracowania}

Materiał empiryczny do prowadzonych analiz został pozyskany $\mathrm{z}$ baz danych Ministerstwa Finansów obejmujących kształtowanie się poszczególnych parametrów sytuacji ekonomicznej JST. Te dane wykorzystane zostały do obliczenia wartości indywidualnych wskaźników zadłużenia (IWZ) samorządów. Drugim istotnym źródłem informacji były zasoby Banku Danych Lokalnych Głównego Urzędu Statystycznego (BDL GUS). Posłużyły one do oceny poziomu absorpcji funduszy strukturalnych w poszczególnych JST.

Zakres czasowy prowadzonych analiz ze względu na zachowanie zasady porównywalności danych ograniczono do okresu 2011-2014. Zakres podmiotowy analizy stanowią wszystkie jednostki samorządu terytorialnego szczebla podstawowego w Polsce (2478 gmin).

Do oceny stopnia wykorzystania funduszy UE posłużono się wskaźnikiem pozyskanego dofinansowania na mieszkańca obliczonym według formuły:

$$
W_{p m}=\frac{W_{d}}{L_{m}}, \text { gdzie: }
$$

$\mathrm{W}_{\mathrm{pm}}$ - wskaźnik wykorzystania funduszy UE na mieszkańca [zł/os.],

$\mathrm{W}_{\mathrm{d}}$ - wykorzystana kwota dofinansowania [zł],

\footnotetext{
${ }^{3}$ Zob. Milewska, A., Jóźwik, M. Organization and changes of local government finance system in view of implementation of participatory budgeting. Acta Scientiarum Polonorum Oeconomia, 13 (4), 2014, s. 125-134. ${ }^{4}$ Paluch Ł., Sroka W., Socio-economic and environmental determinants of sustainable development of rural communes in Małopolska Province. Acta Scientiarum Polonorum Oeconomia, 12 (2), 2013, s. 65-76.
} 
$\mathrm{L}_{\mathrm{m}}-$ liczba mieszkańców gminy [osoby].

Ocenę potencjału zadłużania się samorządów przeprowadzono przy wykorzystaniu Indywidualnego Wskaźnika Zadłużenia (IWZ) obliczanego ze wzoru:

$$
\left(\frac{R+O}{D}\right)_{n} \leq \frac{1}{3} \cdot\left(\frac{D b_{n-1}+S m_{n-1}-W b_{n-1}}{D_{n-1}}+\frac{D b_{n-2}+S m_{n-2}-W b_{n-2}}{D_{n-2}}+\frac{D b_{n-3}+S m_{n-3}-W b_{n-3}}{D_{n-3}}\right)
$$

gdzie:

$\mathrm{R}$ - planowana na rok budżetowy łączna kwota $\mathrm{z}$ tytułu spłat rat kredytów i pożyczek oraz wykup wyemitowanych papierów wartościowych,

$\mathrm{O}$ - planowane na rok budżetowy odsetki od kredytów i pożyczek, odsetki i dyskonto od papierów wartościowych oraz spłaty kwot wynikających $\mathrm{z}$ udzielonych poręczeń i gwarancji,

D - dochody ogółem budżetu w danym roku budżetowym,

$\mathrm{D}_{\mathrm{b}}$ - dochody bieżące,

$\mathrm{S}_{\mathrm{m}}$ - dochody ze sprzedaży majątku,

$\mathrm{W}_{\mathrm{b}}$ - wydatki bieżące,

$\mathrm{n}$ - rok budżetowy, na który ustalana jest relacja.

Do oceny uzyskanych wyników użyto metod statystyki opisowej (wskaźniki struktury, miary rozproszenia i tabele wielodzielcze). W wymiarze teoretycznym podstawę badań stanowiła problematyka ekonomii sektora publicznego.

\section{Wyniki}

Zewnętrzna pomoc dostępna obecnie głównie pod postacią funduszy strukturalnych może stanowić bodziec rozwojowy dla obszarów zacofanych, tym niemniej aby tak się stało, konieczne jest spełnienie kilku warunków. Wykorzystywane fundusze powinny wspierać wzrost ogólnej produktywności czynników produkcji i zwiększanie zatrudnienia ${ }^{5}$. Ważne jest również zastapienie krótkotrwałych efektów popytowych związanych z zastosowaniem środków pomocowych (głównie $\mathrm{w}$ okresie realizacji projektów) trwałymi efektami podażowymi, które występują wówczas, gdy absorpcja środków przyczyniła się do trwałego podniesienia zdolności produkcyjnych gospodarki. Trwałość oznacza utrzymanie się pozytywnych efektów już po zakończeniu wydatkowania funduszy pomocowych ${ }^{6}$. Istotne jest również, aby realizacji zadań inwestycyjnych współfinansowanych z funduszy zewnętrznych towarzyszyły własne działania, podejmowane również $\mathrm{w}$ innych sferach, aby wzmocnić oddziaływanie pozyskanych środków pomocowych ${ }^{7}$. Realizacja projektów inwestycyjnych

\footnotetext{
5 Boldrin, M., Canova, F., Pischke, J. S., Puga, D. Inequality and convergence in Europe's regions: reconsidering European regional policies. Economic policy, 2001, p. 207-253.

${ }^{6}$ Bradley, J., Untiedt, G., Mitze, T. Analysis of the impact of cohesion policy. A note explaining the HERMINbased simulations. Muenster-Dublin, 2007, p.21.

${ }^{7}$ Burnside, C., Dollar, D. Aid, policies, and growth: reply. The American Economic Review, 2004, 94(3), 781784.
} 
współfinansowanych z budżetu UE nie jest jednak możliwa bez zapewnienia wkładu własnego samorządu, a często również bez wydatkowania funduszy na tzw. finansowanie wyprzedzające ${ }^{8}$.

Tabela 1. Zestawienie średnich wartości otrzymanego przez gminy z funduszy UE dofinansowania w latach 2011-2014 (tys. zł)

\begin{tabular}{|l|c|c|c|c|}
\hline Wyszczególnienie & \multicolumn{1}{|l|}{$\mathbf{2 0 1 1}$} & $\mathbf{2 0 1 2}$ & $\mathbf{2 0 1 3}$ & $\mathbf{2 0 1 4}$ \\
\hline Gminy wiejskie & 12215,02 & 15610,16 & 17906,26 & 18749,13 \\
\hline Gminy miejsko-wiejskie & 22801,05 & 27132,27 & 29511,65 & 31019,57 \\
\hline Gminy miejskie & 123767,97 & 148972,99 & 172779,25 & 185110,12 \\
\hline Gminy razem & 28607,08 & 34931,67 & 39912,90 & 42340,59 \\
\hline
\end{tabular}

Źródło: opracowanie na podstawie danych BDL GUS.

Średnie sumaryczne wartości pozyskanych w gminach kwot dofinansowania pochodzących $\mathrm{z}$ funduszy strukturalnych $\mathrm{w}$ analizowanym okresie sukcesywnie wzrastały osiagając poziom ponad $42,3 \mathrm{mln}$ zł. Zanotowana $\mathrm{w}$ pierwszych trzech latach wysoka dynamika wzrostu wykorzystanych kwot dofinansowania uległa wyraźnemu ograniczeniu w 2014 r., co było skutkiem wyczerpywania się funduszy z perspektywy finansowej 2007-2013 i opóźnieniami we wdrażaniu działań z nowego okresu programowania (tab. 1). W generalnej zbiorowości JST dostrzeżono wyraźne zróżnicowanie ze względu na typ gminy, co związane jest głównie z ich wielkością oraz potencjałem ekonomicznym. Na wysokie wartości wykazane w grupie gmin miejskich wpłynęły duże miasta mające status metropolitalny. Wartości zrealizowanych projektów inwestycyjnych zrelatywizowane liczbą osób zamieszkujących poszczególne gminy umożliwiają ocenę zróżnicowania poszczególnych jednostek pod względem skuteczności absorpcji funduszy strukturalnych (tab. 2).

Tabela 2. Zestawienie wybranych cech statystycznych wartości zrealizowanych w gminach projektów UE w przeliczeniu na mieszkańca w latach 2011-2014

\begin{tabular}{|l|r|r|r|r|}
\hline Wyszczególnienie & $\mathbf{2 0 1 1}$ & $\mathbf{2 0 1 2}$ & $\mathbf{2 0 1 3}$ & $\mathbf{2 0 1 4}$ \\
\hline Gminy ogólem & 1920,23 & 2405,77 & 2622,42 & 2726,34 \\
\hline Średnia arytmetyczna & 553,61 & 723,19 & 837,21 & 922,42 \\
\hline I kwartyl & 2141,22 & 2540,29 & 2776,30 & 2937,94 \\
\hline III kwartyl & 1128,89 & 1369,48 & 1560,34 & 1679,91 \\
\hline Mediana & 1843,53 & 2420,83 & 2653,20 & 2759,36 \\
\hline Gminy wiejskie & 461,73 & 615,07 & 713,00 & 801,38 \\
\hline Średnia arytmetyczna & 1925,27 & 2459,54 & 2688,48 & 2809,12 \\
\hline I kwartyl & 998,90 & 1220,48 & 1395,12 & 1497,36 \\
\hline III kwartyl & 2002,01 & 2291,17 & 2443,20 & 2548,68 \\
\hline Mediana &
\end{tabular}

\footnotetext{
${ }^{8}$ Kopańska, A. Efektywność decentralizacji. Analiza zdecentralizowanego dostarczania dóbr o charakterze ponadlokalnym. Wyd. Difin, Warszawa 2014, s. 106.
} 


\begin{tabular}{|l|r|r|r|r|} 
I kwartyl & 706,97 & 842,57 & 986,78 & 1070,60 \\
\hline III kwartyl & 2285,44 & 2541,09 & 2761,23 & 2930,27 \\
\hline Mediana & 1350,71 & 1530,69 & 1703,96 & 1876,32 \\
\hline Gminy miejskie & 2151,85 & 2553,56 & 2816,51 & 2905,95 \\
\hline Średnia arytmetyczna & 892,78 & 1070,23 & 1296,83 & 1366,96 \\
\hline I kwartyl & 2489,83 & 2828,02 & 3133,46 & 3379,08 \\
\hline III kwartyl & 1567,46 & 1772,04 & 2045,54 & 2114,09 \\
\hline Mediana &
\end{tabular}

Źródło: opracowanie na podstawie danych BDL GUS.

Wartość współfinansowanych projektów w przeliczeniu na mieszkańca wykazywała rosnącą tendencję w okresie 2011-2014, tym niemniej dynamika wzrostu była każdego roku niższa. Relatywnie najwyższe kwoty zdołały pozyskać miasta, natomiast przeciętnie najniższe wartości stwierdzono dla gmin miejsko-wiejskich, tym niemniej zróżnicowanie pomiędzy grupami nie było w tym przypadku duże.

Istotną obserwacją jest fakt, że zarówno rozkład w całej zbiorowości generalnej, jak i w poszczególnych grupach gmin charakteryzował się silną prawostronną skośnością. Oznacza to, że obok relatywnie licznej populacji samorządów, które zdołały zrealizować na swoim terytorium stosunkowo niewielkie projekty inwestycyjne, istniała dosyć nieliczna grupa podmiotów, które pozyskały dofinansowanie znacznie przekraczające obliczone wartości średnie (w wielu przypadkach, szczególnie w grupie gmin wiejskich wartości średniej arytmetycznej są zbliżone do III kwartyla rozkładu zmiennej).

Obok analizy wartości zrealizowanych projektów inwestycyjnych ocenie poddano również wskaźnik wartości pozyskanego dofinansowania na mieszkańca (rys. 1).

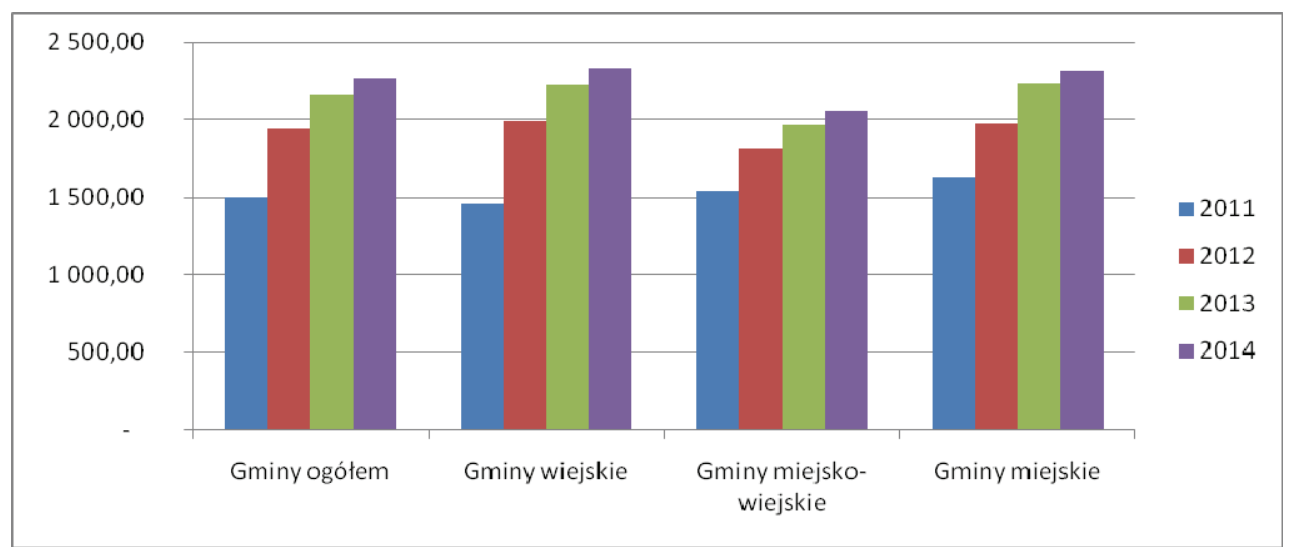

Rysunek 1. Wysokość dofinansowania uzyskanego na realizację inwestycji (zł/mieszkańca gminy) w latach 2011-2014

Źródło: opracowanie na podstawie danych BDL GUS.

Najbardziej dynamiczny wzrost wysokości uzyskanego dofinansowania per capita odnotowano w roku 2012, później tendencja wzrostowa została wyhamowana. Warto zwrócić uwagę, że istniejące na początku okresu analizy różnice pomiędzy różnymi typami gmin $\mathrm{z}$ każdym kolejnym rokiem ulegały ograniczeniu i w ostatnim 
roku jedynie w grupie gmin miejsko-wiejskich obliczone wartości pozyskanych funduszy na mieszkańca ukształtowały się na poziomie ok. $9,1 \%$ niższym w porównaniu do średniej arytmetycznej. Dochodziło zatem do pewnego wyrównywania poziomu uzyskanego dofinansowania pomiędzy poszczególnymi grupami samorządów.

W związku z nowelizacją ustawy o finansach publicznych i wprowadzeniem Indywidualnego Wskaźnika Zadłużenia ${ }^{9}$ zmianie uległy zasady zadłużania się samorządów. Nowe limity zadłużenia wpłynęły głównie na potencjał zaciaggania nowych zobowiązań finansowych przez JST. Jak wskazuje dotychczasowa praktyka samorządowa wiele gmin w celu realizacji inwestycji współfinansowanej z budżetu UE zaciagało kredyty. Ograniczenie takiej możliwości może znacząco zmniejszyć ich potencjał absorpcji funduszy strukturalnych UE. Średnie wartości IWZ wskazują na obniżanie się zdolności gmin do zaciagania zobowiązań (tab. 3).

Tabela 3. Zestawienie wybranych cech statystycznych dla indywidualnego wskaźnika zadłużenia gmin ogółem w latach 2011-2014 (\%)

\begin{tabular}{|l|c|c|c|c|}
\hline Wyszczególnienie & $\mathbf{2 0 1 1}$ & $\mathbf{2 0 1 2}$ & $\mathbf{2 0 1 3}$ & $\mathbf{2 0 1 4}$ \\
\hline Średnia arytmetyczna & 9,71 & 7,79 & 7,13 & 8,02 \\
\hline Wartość najniższa & $-15,99$ & $-15,87$ & $-10,79$ & $-6,23$ \\
\hline Wartość najwyższa & 54,29 & 66,31 & 37,79 & 32,47 \\
\hline Mediana & 9,30 & 7,27 & 6,74 & 7,56 \\
\hline I kwartyl & 5,67 & 4,04 & 4,23 & 5,54 \\
\hline III kwartyl & 13,18 & 10,96 & 9,53 & 10,00 \\
\hline
\end{tabular}

Źródło: opracowanie własne na podstawie danych Ministerstwa Finansów.

Limitowanie zadłużenia jednostek samorządowych według IWZ obowiązuje w Polsce począwszy od 2014 r., tym niemniej przeprowadzone analizy dały podstawę do stwierdzenia, że gdyby ów wskaźnik obowiązywał wcześniej (np. już w 2011 r.), gminy miałyby większą możliwość zadłużania się. Było to spowodowane lepszą sytuacją finansową gmin w latach 2008-2010, a zatem w okresie, z którego pozyskiwane były dane w celu obliczenia IWZ dla 2011 roku. W kolejnych latach kondycja finansowa gmin ulegała sukcesywnemu pogorszeniu, co w konsekwencji wpłynęło na ocenę ich możliwości zadłużania się. Najniższy poziom IWZ osiągnął w 2013 r., zatem wówczas, gdy parametry do jego obliczania pochodziły z okresu 2010-2012, czyli okresu gorszej koniunktury w gospodarce i finansach samorządowych ${ }^{10}$. Obliczone dla 2014 r. wartości są wyższe niż w okresie 2012-2013, co może być interpretowane jako podjęcie przez władze gmin realnych działań zmierzających do dostosowania się do nowej rzeczywistości i takiego planowania budżetów, aby umożliwić również korzystanie z zewnętrznych zwrotnych źródeł finansowania. Warto w tym miejscu zaznaczyć, że

\footnotetext{
${ }^{9}$ Parlińska, A. Zadłużenie samorządów gminnych w Polsce w latach 2005-2012. Nierówności społeczne a wzrost gospodarczy, 2014, Nr 40, s. 193; Ustawa z dnia 27 sierpnia 2009 r. o finansach publicznych (Dz. U. Nr 157, poz. 1240 ze zm.).

10 Zawora J., 2015, Uwarunkowania wykorzystania funduszy Unii Europejskiej wynikające z sytuacji finansowej jednostek samorządu terytorialnego, Finanse Komunalne, 1-2, 47.
} 
limity zadłużenia nie są stosowane do zobowiązań zaciąganych przez JST w związku z realizacją projektów realizowanych ze środków unijnych ${ }^{11}$.

Przedstawiona analiza zróżnicowania średnich wartości pozyskanego dofinansowania per capita w grupach kwartylowych wyodrębnionych ze względu na kształtowanie się wartości indywidualnego wskaźnika zadłużenia nie daje podstaw do rozstrzygających odpowiedzi (tab. 4).

Tabela 4. Zestawienie średnich wartości wskaźnika pozyskanego dofinansowania na mieszkańca ze względu na kształtowanie się indywidualnego wskaźnika zadłużenia

\begin{tabular}{|l|c|c|c|c|c|}
\hline Wyszczególnienie & $\mathbf{2 0 1 1}$ & $\mathbf{2 0 1 2}$ & $\mathbf{2 0 1 3}$ & $\mathbf{2 0 1 4}$ & $\begin{array}{l}\text { Średnia } \\
\mathbf{( 2 0 1 1 - 2 0 1 4 )}\end{array}$ \\
\hline $\begin{array}{l}\text { Gminy o niskim } \\
\text { wskaźniku IWZ }\end{array}$ & 1444,72 & 1808,84 & 1989,29 & 2088,62 & 1832,87 \\
\hline $\begin{array}{l}\text { Gminy o średnim } \\
\text { wskaźniku IWZ }\end{array}$ & 1525,71 & 1817,20 & 2062,17 & 2166,17 & 1892,81 \\
\hline $\begin{array}{l}\text { Gminy o wysokim } \\
\text { wskaźniku IWZ }\end{array}$ & 1313,36 & 1768,29 & 1912,86 & 1977,52 & 1743,01 \\
\hline $\begin{array}{l}\text { Gminy o bardzo wysokim } \\
\text { wskaźniku IWZ }\end{array}$ & 1718,92 & 2374,44 & 2685,53 & 2816,39 & 2398,82 \\
\hline
\end{tabular}

Źródło: opracowanie własne na podstawie danych Ministerstwa Finansów.

Wprawdzie systematycznie relatywnie najwyższe wartości pozyskanych funduszy były charakterystyczne dla grupy gmin posiadających najwyższe wartości wskaźnika IWZ, tym niemniej w pozostałych grupach sytuacja była bardziej skomplikowana. W każdym spośród analizowanych lat jednostki cechujące się najniższą zdolnością do zaciągania zobowiązań zdołały pozyskać przeciętnie nieco wyższe kwoty dofinansowania niż gminy z III grupy kwartylowej. Jakkolwiek limitowanie możliwości zadłużania się oparte na wskaźniku IWZ obowiązuje dopiero od 2014 r., tym niemniej również wcześniej samorządy konstruując własne budżety przygotowywały się do ograniczeń wynikających z jego wprowadzenia. Przeprowadzone analizy umożliwiły wskazanie, że nawet większy potencjał zadłużania się nie gwarantuje wzrostu wskaźników absorpcji funduszy UE w gminach. Skuteczne pozyskiwanie środków pomocowych jest rezultatem oddziaływania również innych czynników ${ }^{12}$.

Absorpcja funduszy strukturalnych przez jednostki samorządu terytorialnego poprzedzona czasochłonnym procesem ich pozyskiwania ${ }^{13}$ oraz następująca później eksploatacja powstałych w wyniku inwestycji obiektów infrastruktury komunalnej powoduje powstawanie kosztów, które muszą zostać pokryte z samorządowego budżetu. Sytuacja taka oddziałuje w konsekwencji na kondycję ekonomiczną JST. Znowelizowane regulacje prawne łączą możliwość zadłużania się samorządów z ich

${ }^{11}$ P. Swianiewicz. (2011). Finanse samorzqdowe: koncepcje, realizacja, polityki lokalne. Wyd. Municipium, Warszawa, s. 188.

${ }^{12}$ Por. Ł. Satoła. Instytucje społeczeństwa obywatelskiego na obszarach wiejskich a sprawność wykorzystania funduszy Unii Europejskiej (na przykładzie województwa małopolskiego), Samorzqd Terytorialny, 2014, Nr 5, s. 30-35; Standar, A. Determinanty pozyskiwania środków pomocowych Unii Europejskiej przez gminy województwa wielkopolskiego. Journal of Agribusiness and Rural Development, 2010, Nr 4(18), s. 97-105.

13 Występują tu również koszty przygotowania niezbędnej do pozyskania funduszy UE dokumentacji strategicznej. Por. Milewska, A. Zarządzanie strategiczne w lokalnej wspólnocie samorządowej jako narzędzie racjonalizacji wydatków publicznych - przegląd podstawowych obszarów. Zeszyty Naukowe Polityki Europejskie, Finanse i Marketing, 2011, Nr 6, s. 63. 
zdolnością do obsługi ${ }^{14}$ długu będącej pochodną ich sytuacji finansowej. W tym celu przeprowadzono ocenę relacji zachodzących pomiędzy dynamiką indywidualnego wskaźnika zadłużenia, a średnimi wartościami pozyskanego dofinansowania (rys. 2).

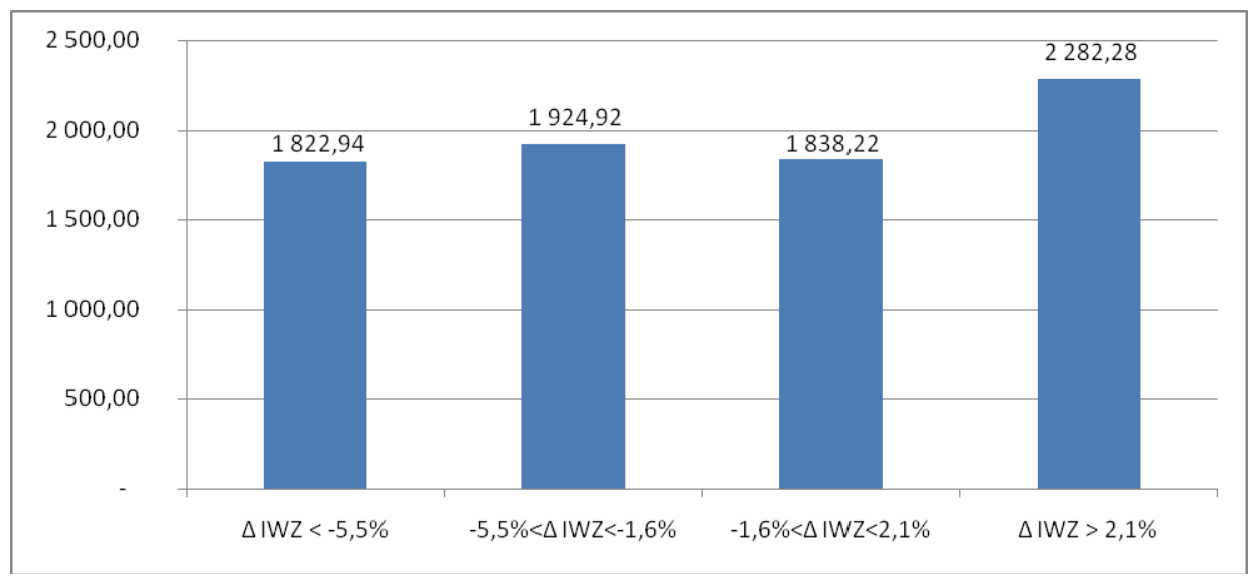

Rysunek 2. Zestawienie średnich wartości wskaźnika pozyskanego dofinansowania na mieszkańca (zł) ze względu na dynamikę indywidualnego wskaźnika zadłużenia gmin

Źródło: opracowanie własne na podstawie danych BDL GUS oraz Ministerstwa Finansów.

Przeprowadzone analizy nie dały podstawy do jednoznacznego stwierdzenia, czy zmiana potencjału do zaciagania zadłużenia przez gminy była związana $\mathrm{z}$ wykorzystaniem funduszy Unii Europejskiej. Największą wartość dofinansowania per capita zanotowano w grupie gmin, gdzie w okresie 2011-2014 nastąił największy wzrost indywidualnego wskaźnika zadłużenia. Różnice pomiędzy pozostałymi grupami były na tyle niewielkie, że nie dawały podstawy do wnioskowania o występowaniu statystycznej zależności pomiędzy zmiennymi. Warto w tym miejscu zaznaczyć, że na kształtowanie się wysokości wskaźnika IWZ oraz jego dynamiki w zdecydowanie większym stopniu niż absorpcja funduszy UE wpływa sfera bieżącej działalności jednostek samorządu terytorialnego. Konstrukcja IWZ w mniejszym stopniu odnosi się bowiem do części budżetu majątkowego, równocześnie wykorzystując głównie kluczowe składniki budżetu bieżącego.

\section{Podsumowanie}

Skuteczne pozyskiwanie i efektywna absorpcja funduszy strukturalnych UE jest dla jednostek samorządu terytorialnego zarówno dużym wyzwaniem organizacyjnym i finansowym, jak i szansą dynamizacji procesów rozwojowych. Dostarczane w zdecentralizowany sposób dobra publiczne zgodne z lokalną skalą preferencji potrzeb mogą determinować przemiany w gospodarce lokalnej. Zewnętrzne środki finansowe są w stanie kreować warunki do trwałego rozwoju gospodarczego pod warunkiem właściwego ich ukierunkowania i efektywnego zastosowania.

\footnotetext{
${ }^{14}$ Por. Marchewka-Bartkowiak, K., Wiśniewski, M. Indywidualny wskaźnik zadłużenia JST - ocena krytyczna i propozycje zmian. Analizy BAS, 2012, Nr 21(88), s. 4.
} 
Pozyskiwanie funduszy pomocowych powoduje jednak konieczność dokonywania znaczących wydatków z budżetów samorządów. Wydatki te w związku z ograniczonymi możliwościami gminnych budżetów często finansowane są z kredytów. Znowelizowane zasady zadłużania się oznaczają dla JST konieczność limitowania długu w oparciu o wskaźniki indywidualne.

Przeprowadzone analizy dowiodły dużego zróżnicowania wykorzystania funduszy strukturalnych przez polskie gminy zarówno $\mathrm{w}$ wartościach bezwzględnych, jak i w ujęciu relatywnym. Dostrzeżono duże spolaryzowanie w tym zakresie, tzn. obok stosunkowo niezbyt licznej grupy jednostek, które zdołały pozyskać wysokie kwoty z funduszy strukturalnych istniała liczna grupa, dla której obliczone wskaźniki dofinansowania kształtowały się na niskim poziomie. Wartości pozyskanego dofinansowania na mieszkańca pozwoliły stwierdzić, że najniższe kwoty środków pomocowych wykorzystały gminy miejsko-wiejskie, tym niemniej różnice pomiędzy typami gmin nie były w tym przypadku duże.

$\mathrm{Na}$ podstawie przeprowadzonych analiz nie można jednoznacznie stwierdzić występowania zależności pomiędzy wartością absorpcji środków finansowych przez gminy a indywidualnymi wskaźnikami zadłużenia. Istnienie nowych wskaźników limitujących możliwość zadłużania się może oddziaływać ograniczająco na przyszłe zdolności absorpcyjne samorządów. Sytuacja taka może wystapić szczególnie w grupie dotychczas najaktywniejszych gmin, które zaciagały zobowiązania na realizację współfinansowanych $\mathrm{z}$ funduszy UE inwestycji. Konieczność spłaty zobowiązań kredytowych spowoduje spadek ich potencjału do podejmowania, realizacji i finansowania nowych zadań inwestycyjnych.

\section{Bibliografia}

Boldrin, M., Canova, F., Pischke, J. S., Puga, D. (2001). Inequality and convergence in Europe's regions: reconsidering European regional policies. Economic policy, p. 207-253.

Bradley, J., Untiedt, G., Mitze, T. (2007). Analysis of the impact of cohesion policy. A note explaining the HERMIN-based simulations. Muenster-Dublin.

Burnside, C., Dollar, D. (2004). Aid, policies, and growth: reply. The American Economic Review, 94(3), 781-784.

Kopańska, A. (2014). Efektywność decentralizacji. Analiza zdecentralizowanego dostarczania dóbr o charakterze ponadlokalnym. Wyd. Difin, Warszawa.

Marchewka-Bartkowiak, K., Wiśniewski, M. (2012). Indywidualny wskaźnik zadłużenia JST ocena krytyczna i propozycje zmian, Analizy BAS, 21 (88), s. 1-6.

Milewska, A. (2011). Zarządzanie strategiczne w lokalnej wspólnocie samorządowej jako narzędzie racjonalizacji wydatków publicznych - przegląd podstawowych obszarów. Zeszyty Naukowe Polityki Europejskie, Finanse i Marketing, $\mathrm{Nr}$ 6(55), s. 57-66.

Milewska, A., Jóźwik, M. (2014). Organization and changes of local government finance system in view of implementation of participatory budgeting. Acta Scientiarum Polonorum Oeconomia, 13 (4), $125-134$.

Oates W., 1972, Fiscal federalism, Harcourt Brace Jovanovich, New York.

Paluch Ł., Sroka W., (2013) Socio-economic and environmental determinants of sustainable development of rural communes in Małopolska Province. Acta Scientiarum Polonorum Oeconomia, 12 (2), p. 65-76.

Parlińska, A. (2014). Zadłużenie samorządów gminnych w Polsce w latach 2005-2012.

Nierówności społeczne a wzrost gospodarczy, (40), 191-200. 
Prus P., Wawrzyniak B. M. Zarządzanie projektami i funkcje gmin w zakresie programów rozwoju obszarów wiejskich. Studia i Materialy Polskiego Stowarzyszenia Zarzqdzania Wiedza, 2011, nr 44, s. 77-92.

Satoła Ł. (2014). Instytucje społeczeństwa obywatelskiego na obszarach wiejskich a sprawność wykorzystania funduszy Unii Europejskiej (na przykładzie województwa małopolskiego), Samorzad Terytorialny, Nr 5, s. 24-35.

Standar, A. (2010). Determinanty pozyskiwania środków pomocowych Unii Europejskiej przez gminy województwa wielkopolskiego. Journal of Agribusiness and Rural Development, 4(18), 97 105.

Swianiewicz P. (2011). Finanse samorzadowe: koncepcje, realizacja, polityki lokalne. Wyd. Municipium, Warszawa.

Zawora J., (2015). Uwarunkowania wykorzystania funduszy Unii Europejskiej wynikające z sytuacji finansowej jednostek samorządu terytorialnego, Finanse Komunalne, 1-2, 43-54.

Ustawa z dnia 27 sierpnia 2009 r. o finansach publicznych (Dz. U. Nr 157, poz. 1240 ze zm.).

\section{Summary}

European integration has significantly changed the conditions for the functioning of local government units mainly due to the availability of structural funds. Nowadays, many activities undertaken by the communities, especially the investment is carried out with the participation of co-financing within the EU regional policy instruments. The obtained funds give not only support to local budgets, but also cause an increase in expenditures, which are often financed with loans. The aim of the article is to identify the relations between municipal investments realized with the financial support and the newly introduced debt indicators. Polish municipalities differed significantly among the utilization of EU funds. New debt limits may reduce the absorption capacity of local governments as a consequence of interest payments on loans taken out in the past.

Keywords: public sector economics, structural funds, municipality, regional policy, financial situation of municipalities, debt

\section{Informacje o autorze:}

\section{Dr inż. Lukasz Satoła}

Uniwersytet Rolniczy w Krakowie

Instytut Ekonomiki i Zarządzania Przedsiębiorstwami

Al. Mickiewicza 21

31-120 Kraków

tel. (12) 6624387

e-mail: 1satola@ar.krakow.pl 